\title{
GROUNDED RESEARCH DALAM BIDANG ILMU AL-QUR'AN DAN TAFSIR
}

\author{
Syamsul Mawardi Marna \\ UIN Sunan Ampel Surabaya \\ kangshul98@gmail.com
}

\section{Abstrak}

Al-Qur'an merupakan kitab terakhir yang diturunkan oleh Allah kepada Nabi Muhammad untuk umatnya sebagai mukjizat terbesar bagi sang Nabi, pedoman bagi manusia. Al-Qur'an diturunkan oleh Allah Swt sebagai petunjuk bagi manusia. Kehadirannya dijelaskan dalam al-Qur'an untuk memberi putusan dan jalan keluar terbaik bagi problem-problem kehidupan manusia. Inilah fungsi pertama kehadirannya sebagai upaya mewujudkan kehidupan manusia yang jauh lebih baik di dunia maupun di akhirat nanti.Penafsiran al-Qur'an senantiasa mengalami perkembangan seiring berjalannya waktu. satu ayat al-Qur'an bahkan bisa memiliki berbagai makna penafsiran berdasarkan para mufassir. Salah satu metode penelitian yang berkembang saat ini adalah grounded theory atau grounded re-search, yang menekankan penemuan teori dari data observasi empirik di lapangan dengan metode induktif (menemukan teori dari sejumlah data).

Kata kunci: Grounded Research, Metode Induktif, Ilmu al-Qur'an, Tafsir.

\section{Abstract}

The Qur'an is the last book that was revealed by Allah to the Prophet Muhammad for his people as the greatest miracle for the Prophet, the guide for mankind. The Qur'an was revealed by Allah Swt. as a guide for humans. Its presence is described in the Koran to provide the best decisions and solutions for the problems of human life. This is the first function of its presence as an effort to create a better human life in this world and in the hereafter. The interpretation of the Qur'an continues to develop over time. One verse of the Qur'an can even have 
various interpretive meanings based on the commentators. One of the research methods currently developing is Grounded Theory or Grounded Research, where it emphasizes theoretical findings from empirical observational data in the field using the inductive method (finding theory from a number of data).

Keywords: Grounded Research, Inductive Method, Qur'anic Science, Exegesis.

\section{Pendahuluan}

Tafsir al-Qur'an adalah ilmu pengetahuan untuk memahami dan menafsirkan yang berkaitan dengan al-Qur'an dan isinya berfungsi sebagai mubayyin (pemberi penjelasan), menjelaskan tentang arti dan kandungan al-Qur'an, khususnya terkait ayat-ayat yang tidak dipahami dan samar artinya. Kebutuhan umat Islam terhadap tafsir al-Qur'an, sehingga makna-maknanya dapat dipahami secara penuh dan menyeluruh, merupakan hal yang mendasar dalam rangka melaksanakan perintah Allah Swt. sesuai yang dikehendaki-Nya.

Dalam memahami dan menafsirkan al-Qur'an diperlukan bukan hanya pengetahuan bahasa Arab, tetapi juga berbagai macam ilmu pengetahuan yang menyangkut al-Qur'an dan isinya. Ilmu untuk memahami al-Qur'an ini disebut dengan Ushul Tafsir atau biasa dikenal dengan Ulumul Qur'an (ilmuilmu al-Qur'an). Terdapat tiga bentuk penafsiran yaitu tafsîr bil ma'tsûr, attafsîr bir ra'yi, dan tafsir isyari, dengan empat metode, yaitu ijmâli, tahlîli, muqârin, dan maudhûi. Sedangkan dari segi corak lebih beragam, ada yang bercorak sastra bahasa, fikih, teologi, fil- safat, tasawuf, ilmiyah dan corak sastra budaya kemasyarakatan.

Usaha menafsirkan al-Qur'an dimulai sejak zaman para sahabat Nabi. 'Ali ibn Abi Thâlib (w. 40 H), 'Abdullah ibn 'Abbâs (w. 68 H), 'Abdullah Ibn Mas'ûd (w. $32 \mathrm{H}$ ) dan Ubay ibn Ka'ab (w. $32 \mathrm{H}$ ) adalah di antara para sahabat yang terkenal banyak menafsirkan ayatayat al-Qur'an dibandingkan dengan sahabat-sahabat yang lain. ${ }^{1}$

Penafsiran al-Qur'an selalu mengalami perkembangan seiring perkembangan zaman. Satu ayat al-Qur'an bahkan bisa mempunyai berbagai makna penafsiran berdasarkan para mufassir. Salah satu metode penelitian yang berkembang dewasa ini adalah grounded theory (grounded research) yang menekankan penemuan teori melalui data observasi empirik di lapangan dengan metode induktif (menemukan teori dari sejumlah data).

\section{Grounded Research}

Grounded research (grounded theory) adalah suatu metode penelitian yang berdasarkan pada fakta dan menggu-

${ }^{1}$ As-Suyuthi, Al-Itqan fi Ulum al-Qur'an (Beirut: Dar al-Fikr, 1979), 187.. 
nakan analisa perbandingan bertujuan untuk mengadakan generalisasi empiris, menetapkan konsep-konsep, membuktikan teori dan mengembang-kan teori di mana pengumpulan data dan analisisnya secara bersamaan. Lebih lanjut, tujuan dari grounded research adalah untuk mengadakan generalisasi empiris, menetapkan konsep-konsep, membuktikan teori dan mengembangkan teori. Selain itu, penelitian jenis ini bertujuan untuk melakukan spesifikasi konsep dan memverifikasi terhadap teori yang sedang dikembangkan dan diperiksa dalam hubungannya dengan data yang ditemukan. Dalam penelitian grounded research digunakan metode perbandingan yang bertujuan untuk menentukan seberapa besar gejala tersebut berlaku umum.

\section{Ciri-ciri Grounded Research}

Nazir mengungkapkan bahwa terdapat beberapa ciri penelitian jenis grounded research antara lain: ${ }^{2}$

a. Penggunaan data sebagai sumber teori;

b. Menonjolkan peranan data dalam penelitian;

c. Pengumpulan data dan analisis dilakukan dalam waktu yang bersamaan;

d. Perumusan hipotesa berdasarkan kategori.

2 M. Nazir, Metodologi Penelitian (Jakarta: Ghalia Indonesia, 1988)..

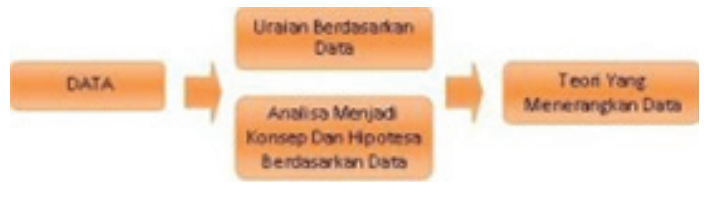

Dari gambar tersebut, dapat diketahui penelitan pada grounded research merupakan penelitian yang berawal dari data yang ada. Dalam penelitian jenis ini, peneliti langsung datang ke lapangan tanpa membawa rangcangan konseptual, proposisi, atau teori-teori tertentu seperti yang dilakukan pada penelitian kualitatif pada umumnya. Data pada penelitian ini menjadi sumber teori, dan teori tersebut dinamakan grounded karena berdasarkan data. Sehingga teori yang nantinya dihasilkan adalah berdasarkan pada data yang ada.

\section{Langkah-langkah Grounded Re- search}

\section{a. Merumuskan Masalah Penelitian}

Perumusan masalah pada grounded research dilakukan secara bertahap. Pada tahap awal atau sebelum pengumpulan data, rumusan masalah dikemukakan secara garis besar yang berfungsi sebagai panduan untuk mengumpulkan data. Selanjutnya, datadata yang bersifat umum tersebut dikumpulkan. Kemudian, rumusan masalah dipersempit dan difokuskan sesuai sifat data yang dkumpulkan. Rumusan masalah yang kedua digunakan peneliti sebagai panduan untuk menyusun teori. Dengan begitu, dapat diketahui bahwa 
dalam merumuskan masalah pada penelitian grounded research dilakukan tidak hanya sekali.

\section{b. Melakukan Penjaringan Data}

Data dalam penelitian grounded research digali dari berbagai fenomena atau perilaku yang sedang berlangsung yang digunakan untuk melihat prosesnya serta untuk menangkap hal-hal yang bersifat kausalitas (sebab akibat).

\section{c. Analisis Data}

Tahap-tahap analisis data yakni: (a) open coding, peneliti membentuk beberapa kategori awal informasi mengenai fenomena yang diteliti dengan menyeleksi data ke dalam jenis yang relevan; (b) axial coding, peneliti memilih salah satu kategori dan memosisikannya sebagai inti fenomena yang sedang diteliti; (c) selective coding, peneliti menulis teori dari berbagai hubungan dari seluruh kategori dalam tahap axial coding sebelumnya.

\section{d. Penyusunan Teori}

Di dalam proses penyusunan teori meliputi analisis dari hubungan yang terjadi pada keseluruhan kategori yang telah ditemukan sebelumnya. Creswell mengemukakan bahwa teori dapat dituliskan dalam satu bentuk narasi yang menggambarkan kesalingterkaitan seluruh kategori.

\section{e. Validasi Teori}

Proses validasi ini dilakukan setelah teori selesai dirumuskan, dengan cara membandingkannya dengan prosesproses sejenis pada penelitian sebelumnya. Creswell ${ }^{3}$ mengemukakan bahwa penilai luar, seperti partisipan juga daapt dimintai untuk memeriksa keabsahan teori maupun validitas dan kredibilitas data.

\section{f. Penulisan Laporan Penelitian}

Creswell ${ }^{4}$ mengemukakan bahwa struktur laporan penelitian grounded research sangat tergantung pada desain yang digunakan. Jika desain yang digunakan adalah pendekatan sistematik, laporan penelitian relatif mirip dengan struktur laporan penelitian kuantitatif, yang mencakup bagian-bagian perumusan masalah, metode penelitian, analisis dan diskusi, dan hasil penelitian. Jika desain yang digunakan adalah pendekatan emerging atau konstruktivis, struktur laporan penelitikan bersifat fleksibel.

Secara lebih singkat, Nazir mengemukakan bahwa terdapat langkah-langkah pokok dari grounded reseacrh: ${ }^{5}$ a) menentukan masalah yang ingin diselidiki; b) mengumpulkan data; c) meng-

3 J.W. Cresswell, Research Design, trans. Achmad Fawaid (Yogyakarta: Pustaka Belajar, 2008).

\footnotetext{
4 Cresswell.

5 Nazir, Metodologi Penelitian, 90-91.
} 
analisis dan memberikan penjelasan; dan d) membuat laporan penelitian.

\section{g. Kelemahan Grounded Research}

Vredenbregt (1981) dalam Nazir 6 mengungkapkan beberapa kelemahan dari penelitian grounded research antara lain sebagai berikut:

1) Grounded research menggunakan analisa perbandingan dan menyifatkan analisis perbandingan sebagai penemuan yang baru karena penelitian ini tidak menggunakan probability sampling, maka generalisasi yang dibuat akan mengandung banyak bias.

2) Akhir satu penelitian bergantung pada subjektivitas peneliti. Apakah hasilnya suatu teori atau hanya satu generalisasi saja, tidak ada seorang pun yang tahu kecuali peneliti.

3) Secara umum dapat disimpulkan bahwa teori yang diperoleh dalam grounded research tidak didasarkan atas langkah-langkah sistematis melalui siklus empiris dari metode ilmiah. Spekulasi dan sifat impresionistis menjadi kelemahan utama grounded research sehingga diragukan adanya representativitas, validitas, dan reliabilitas dari data.

4) Grounded research dapat disamakan dengan pilot studi atau exploratory research.

\footnotetext{
6 Nazir, 92.
}

5) Karena dalam memberikan definisi banyak sekali digunakan aksioma atau asumsi mereka sendiri, maka sukar sekali dinilai dengan metodemetode umum lainnya yang sering dilakukan dalam penelitian kemasyarakatan.

\section{Pembahasan}

Berdasarkan pemaparan di atas, maka penulis berusaha menyajikan pembahasan temuan dari penelitian ini, yaitu bahwa metode grounded research dapat digunakan sebagai metode dalam penafsiran al-Qur'an.

Menurut Baidan, ${ }^{7}$ penelitian dasar dalam kajian tafsir sejak zaman klasik telah diterapkan para ulama. Contohnya, teori yang ditemukan oleh Imam al-Syafi'i bahwa setiap kalimat perintah yang disabdakan Allah secara mutlak (secara lepas, tanpa dikaitkan dengan kondisi apapun) wajib ditaati, seperti perintah ibadah shalat lima waktu sebagai kewajiban syar'at semua umat Islam; kapan dan di mana pun mereka berada; bahkan dalam keadaan sakit sekalipun, mereka tetap diuntut menunaikannya. Begitu pula larangan yang disampaikan secara mutlak, pun harus ditinggalkan secara total; sedikit pun tidak boleh ditawar seperti larangan melakukan perbuatan yang menjurus

\footnotetext{
7 Nashruddin Baidan, Konsepsi Taqwa Perspektif al-Qur'an (Yogyakarta: Pustaka Belajar, 2015), 73.
} 
kepada perzinaan atau prostitusi. Para ulama sejak dulu sepakat menyatakannya 'haram'.

Teori ini ditemukan oleh al-Syafi'i setelah dilakukan pelacakan secara eksploratif terhadap semua kalimat perintah dan larangan yang disabdakan Allah di dalam al-Qur'an dan temuan tersebut diakui oleh para ulama sampai sekarang. Jadi jelas bahwa untuk menghasilkan sebuah teori, maka sarananya ialah menggunakan basic research tidak yang lain. Dari itu penelitian model ini amat diperlukan, terutama dalam pengembangan keilmuan (akademik).

Begitu pula dengan pendekatan yang dikembangkan Abdullah Saeed, Pendekatan kontekstual Abdullah Saeed adalah salah satu di antara sekian pendekatan kontemporer yang berusaha menangkap makna tersembunyi dari teks al-Qur'an sebagai counter terhadap maraknya pendekatan legalistik-literalistik yang digunakan mayoritas umat Islam selama ini. Dari segi metodologi penafsirannya, Saeed menekankan pentingnya mengetahui konteks saat pewahyuan al-Qur'an dan begitu juga konteks saat ini agar pesan-pesan universal al-Qur'an dapat diterapkan di kehidupan kontemporer yang dinamis.

Dalam menyusun langkah penafsiran, Saeed mengembangkan teori double movement atau gerakan ganda Fazlur Rahman dan kemudian merumuskan metodologi sendiri. Selain itu, konsep hierarki nilai yang digagas Saeed juga merupakan kelanjutan dari general principles Rahman. Konsep hierarki nilai ini sangat penting untuk diketahui oleh pegiat kajian al-Qur'an kontemporer karena hierarki nilai ini menawarkan cara pandang baru bagaimana seharusnya menyikapi ayat-ayat ethicolegal dalam al-Qur'an. Dalam hierarki nilai, semakin sering suatu nilai disebutkan dalam al-Qur'an dan ditekankan pada masa Nabi, semakin penting dan signifikan nilai tersebut, begitu juga sebaliknya. ${ }^{8}$

Merujuk pada teori yang digunakan, yaitu grounded research, di mana teori ini berdasarkan pada fakta dan menggunakan analisis perbandingan bertujuan untuk membuat generalisasi empiris, menetapkan konsep-konsep, membuktikan teori dan mengembangkan teori di mana pengumpulan data dan analisa data berjalan pada waktu yang bersamaan. Teori ini semisal dengan kebenaran al-Qur'an, di mana kandungannya berdasarkan pada fakta.

Bukti-bukti keautentikan al-Qur'an salah satunya adalah Bacaan asli alQur'an selalu dicantumkan. Al-Qur'an terbitan Indonesia, diberi tulisan bacaan al-Qur'an dengan huruf latin akan tetapi tulisan asli, bahasa asli (Arab) tetap ditulis, dibawahnya baru diberi tulisan atau

\footnotetext{
${ }^{8}$ Abdullah Saeed, Interpreting the Qur'an toward a Contemporary Approach (London \& New York: Routledge, 2006).
} 
bacaan dengan huruf Latin, begitu juga di negara-negara lain. Hal ini dimaksudkan untuk menjaga keautentikan alQur'an.

Al-Qur'an autentik (asli) dari Allah bukan buatan Rasulullah, hal ini sudah dimuat dalam QS. Yunus [10]: 37.

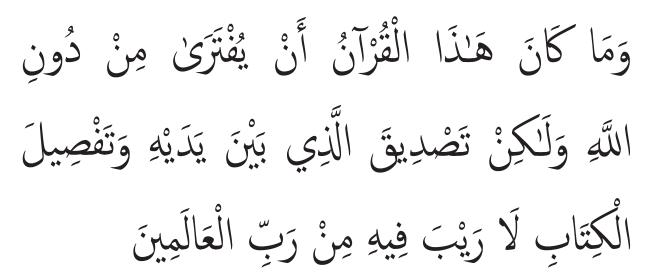

Tidaklah mungkin al-Qur'an ini dibuat oleh selain Allah; akan tetapi (al-Qur'an itu) membenarkan kitab-kitab yang sebelumnya dan menjelaskan hukum-hukum yang telah ditetap-kannya, tidak ada keraguan di dalamnya, (diturunkan) dari Tuhan semesta alam.

Selanjutnya, juga fakta mengenai penciptaan manusia. Penciptaan manusia dan aspek-aspeknya yang luar biasa itu ditegaskan dalam banyak ayat. Beberapa informasi di dalam ayat-ayat ini sedemikian rinci sehingga mustahil bagi orang yang hidup di abad ke-7 untuk mengetahuinya. Beberapa di antaranya sebagai berikut:

1) Manusia tidak diciptakan dari mani yang lengkap, tetapi dari sebagian kecilnya.

2) Sel kelamin laki-laki yang menentukan jenis kelamin bayi.
3) Janin manusia melekat pada rahim sang ibu bagaikan lintah.

4) Manusia berkembang di tiga kawasan yang gelap di dalam rahim.

Orang-orang zaman dulu ketika al-Qur'an diturunkan, pasti mengetahui bahwa bahan dasar kelahiran berhubungan dengan mani laki-laki yang terpancar selama persetubuhan seksual. Fakta bahwa bayi lahir sesudah jangka waktu sembilan bulan tentu saja merupakan peristiwa yang gamblang dan tidak me-merlukan penyelidikan lebih lanjut. Namun, sedikit informasi yang dikutip di atas itu berada jauh di luar pengertian orang-orang yang hidup pada masa itu. Ini baru disahihkan oleh ilmu pengetahuan abad ke-20.

Kami telah menciptakan kamu; maka mengapa kamu tidak membenarkan? Adakah kamu perhatikan nutfah (benih manusia) yang kamu pancarkan? Kamukah yang menciptakannya? Ataukah Kami yang menciptakannya? (QS. al-Waqiah: [56]: 57-59).

Selanjutnya, fakta tentang gunung. Gunung ada atau muncul karena tumbukan lempengan-lempengan raksasa yang membentuk kerak bumi. Lempengan yang lebih kuat menyelip ke bawah. Sedangkan lempengan yang lemah melipat ke atas dan membentuk dataran tinggi dan gunung banyak sekali 
fungsi gunung, antara lain penahan guncangan, penyalur pembuangan tenaga panas bumi, penyubur tanah dan lain lainnya. Al-Qur'an menjelaskan fungsi gunung dalam beberapa ayat dalam alQur'an, antara lain:

Dan telah Kami jadikan di bumi ini gunung-gunung yang kokoh supaya bumi itu (tidak) goncang bersama mereka, dan telah Kami jadikan (pula) di bumi itu jalan-jalan yang luas, agar mereka mendapat petunjuk (QS. al-Anbiya [21]: 31).

Bukankah Kami telah menjadikan bumi itu sebagai hamparan? dan gunung-gunung sebagai pasak? (QS. an-Naba' [78]: 6-7).

Selanjutnya adalah fenomena api di dasar lautan. Fenomena api di dasar lautan ini ditemukan oleh seorang ahli geologi asal Rusia, Anatol Sbagovich dan Yuri Bagdanov dan ilmuan asal Amerika Serikat, Rona Clint ketika mereka sedang meneliti tantang kerak bumi dan patahannya di dasar lautan di lepas pantai Miami. Mirip seperti lava cair yang mengalir dan disertai dengan abu vulkanik seperti gunung berapi di daratan yang memiliki suhu mencapai $231^{\circ} \mathrm{C} .{ }^{9}$

9 "Subhanallah, Inilah Mukjizat Alquran tentang Api di Dasar Lautan," Republika, 7 Maret 2012; https://www.republika.co.id/
Meskipun sangat panas, tetapi tidak cukup untuk memanaskan seluruh air yang ada di atasnya begitupun seluruh air yang ada diatas nya tersebut tidak mampu memadamkan api panas tersebut, sungguh keajaiban yang luar biasa. Lempengan-lempengan ini terletak di lembah atau dasar samudra. Ia menahan lelehan bebatuan panas yang dapat membuat laut meluap-luap. Namun, banyaknya air di lautan dapat meredam panasnya bara yang memiliki suhu panas tinggi ini lebih dari $1000^{\circ} \mathrm{C}$ mampu menguapkan air laut. Ini adalah salah satu di antara banyak fakta-fakta bumi lainnya yang mengejutkan para ilmuwan. Sebenarnya al-Qur'an sudah menyebutkan tentang api di dasar lautan ini.

Demi bukit. Dan kitab yang tertulis. Pada lembaran yang terbuka. Dan demi Baitul Makmur (Ka'bah). Dan demi surga langit yang ditinggikan. Dan demi laut, yang di dalam tanah ada api (QS. at-Thur [52]: 1-6).

Ketahuilah, sungguh jika dia tidak berhenti (berbuat demikian) niscaya Kami tarik ubun-ubunnya, (yaitu) ubun-ubun orang yang mendustakan lagi durhaka (QS. alAlaq [96]: 15-16).

berita/ m0i74b/subhanallah-inilah-mukjizatalquran-tentang-api-di-dasar-lautan, diakses 2 Desember 2020. 
Ungkapan "ubun-ubun orang yang mendustakan lagi durhaka" dalam ayat di atas sungguh menarik. Penelitian yang dilakukan di tahun-tahun belakangan mengungkapkan bahwa bagian prefrontal, yang bertugas mengatur fungsi-fungsi khusus otak, terletak pada bagian depan tulang tengkorak.

Para ilmuwan hanya mampu menemukan fungsi bagian ini selama kurun waktu 60 tahun terakhir, sedangkan al-Qur'an telah menyebutkannya 1400 tahun lalu. Jika dilihat bagian dalam tulang tengkorak, di bagian depan kepala, akan ditemukan daerah frontal cerebrum (otak besar). Jelas bahwa ungkapan "ubun-ubun orang yang mendustakan lagi durhaka" benar-benar merujuk pada penjelasan di atas. Fakta yang hanya dapat diketahui para ilmuwan selama 60 tahun terakhir ini, telah dinyatakan Allah dalam al-Qur'an sejak dulu.

Seiring dengan perkembangan ilmu pengetahuan, ilmuwan menemukan fakta bahwa besi adalah berasal dari langit. Ilmu sains memberi informasi kepada kita bahwa besi adalah logam berat yang tidak dapat dihasilkan oleh bumi kita sendiri. Lebih tepatnya besi berasal dari Asteroid (kaya akan unsur besi) yang menabrak bumi (awal pembentukan bumi). Fakta tentang manfaat besi dan asal besi juga sudah tertulis dalam QS. al-Hadiid [57]: 25.
Sesungguhnya Kami telah mengutus Rasul-rasul Kami dengan membawa bukti-bukti yang nyata dan telah Kami turunkan bersama mereka al-Kitab dan neraca (keadilan) supaya manusia dapat melaksanakan keadilan. Dan Kami turunkan (anzalnaa) besi yang padanya terdapat kekuatan yang hebat dan berbagai manfaat bagi manusia, (supaya mereka mempergunakan besi itu) dan supaya Allah mengetahui siapa yang menolong (agama)-Nya dan Rasul-rasulNya, padahal Allah tidak dilihatnya. Sesungguhnya Allah Mahakuat lagi Mahaperkasa.

Kata anzalnaa memiliki arti "kami turunkan" digunakan untuk menunjuk besi. Apabila diartikan secara kiasan kata anzalnaa menjelaskan bahwa besi diciptakan untuk memberi manfaat bagi manusia. Apabila mengartikan kata itu secara harfiah, yakni "secara bendawi diturunkan dari langit", maka diperoleh arti bahwa besi diturunkan dari langit. Fakta yang ilmuwan baru saja temukan ternyata 14 abad lalu sudah tertulis di dalam al-Qur'an.

Selanjutnya mengenai fakta-fakta peristiwa dan hal-hal seputar langit. Fakta-fakta yang disampaikan dalam al-Qur'an ini telah ditemukan melalui pengamatan astronomis di zaman kita. Menurut perhitungan para ahli astronomi, matahari bergerak dengan 
kecepatan luar biasa yang mencapai $720 \mathrm{ribu} \mathrm{km/jam} \mathrm{ke} \mathrm{arah} \mathrm{bintang} \mathrm{Vega}$ dalam sebuah garis edar yang disebut Solar Apex. Hal ini berarti matahari bergerak sejauh kurang lebih 17.280.000 kilometer dalam sehari. Bersama matahari, semua planet dan satelit dalam sistem gravitasi matahari juga berjalan menempuh jarak ini. Selanjutnya, semua bintang di alam semesta berada dalam suatu gerakan serupa yang terencana.

Mengenai Fenomena tata surya dan garis edar sudah tertulis di dalam alQur'an 0sebagai berikut.

Dan Dialah yang telah menciptakan malam dan siang, matahari dan bulan. Masing-masing dari keduanya itu beredar di dalam garis edarnya (QS. al-Anbiya [21] :33).

Dan matahari berjalan di tempat peredarannya. Demikianlah ketetapan Yang Maha Perkasa lagi Maha Mengetahui.telah Kami tetapkan bagi bulan manzilah-manzilah, sehingga (setelah dia sampai ke manzilah yang terakhir) kembalilah dia sebagai bentuk tandan yang tua. Tidaklah mungkin bagi matahari mendapatkan bulan dan malampun tidak dapat mendahului siang. Dan masing-masing beredar pada garis edarnya (QS. Yaasin [36]: 38-40).

Selanjutnya mengenai fakta bawah laut yang gelap. Manusia tidak mampu menyelam di laut dengan kedala-man di bawah 40 meter tanpa peralatan khusus. Dalam sebuah buku berjudul Oceans juga dijelaskan, pada kedalaman 200 meter hampir tidak dijumpai cahaya, sedangkan pada kedalaman 1000 meter tidak terdapat cahaya sama sekali. Kondisi dasar laut yang gelap baru bisa diketahui setelah penemuan teknologi canggih. Namun, al-Qur'an telah menjelaskan keadaan dasar lautan semenjak ribuan tahun lalu sebelum teknologi itu ditemukan. QS. an-Nur ayat 40 menjelaskan mengenai fakta ilmiah ini.

Atau seperti gelap gulita di lautan yang dalam, yang diliputi oleh ombak, yang di atasnya ombak (pula), di atasnya (lagi) awan; gelap gulita yang tindih-bertindih, apabila dia mengeluarkan tangannya, tiadalah dia dapat melihatnya, (dan) barang siapa yang tiada diberi cahaya (petunjuk) oleh Allah tiadalah dia mempunyai cahaya sedikit pun (QS. an-Nur [24]: 40).

Albert Einstein pada awal abad ke-20 berhasil menemukan teori relativitas waktu. Teori ini menjelaskan bahwa waktu ditentukan oleh massa dan kecepatan. Waktu dapat berubah sesuai dengan keadaannya. Beberapa ayat dalam al-Qur'an juga telah mengisyaratkan adanya relativitas waktu ini, di antaranya dalam QS. al-Hajj, QS. asSajdah, dan QS. al-Ma'aarij, berikut ini. 
Dan mereka meminta kepa-damu agar azab itu disegerakan, padahal Allah sekali-kali tidak akan menyalahi janji-Nya. Sesungguhnya sehari di sisi Tuhanmu adalah seperti seribu tahun menurut perhitunganmu (QS. al-Hajj [22]: 47).

Dia mengatur urusan dari langit ke bumi, kemudian (urusan) itu naik kepada-Nya dalam satu hari yang kadarnya (lamanya) adalah seribu tahun menurut perhitunganmu (QS. as-Sajdah [32]: 5).

Malaikat-malaikat dan Jibril naik (menghadap) kepada Tuhan dalam sehari yang kadarnya lima puluh ribu tahun (QS. al-Ma’arij [70]: 4).

Beberapa ayat al-Qur'an lainnya menjelaskan, manusia terkadang merasakan waktu secara berbeda, waktu yang singkat dapat terasa lama dan begitu juga sebaliknya.

Selanjutnya mengenai fenomena sungai dasar laut. Fenomena sungai di dasar laut ditemukan oleh Ilmuan asal Prancis bernama Jaques Yves Cousteau dia berhasil menemukan air tawar yang mengalir di antara air laut yang asin di dasar lautan. Para ahli menyebut fenomena ini sebagai lapisan hidrogen sulfida, karena air yang mengalir di sungai dasar laut ini memiliki rasa air tawar. Selain itu sungai dasar laut ini ditumbuhi daun-daunan dan pohon. Sub- hanallah. Fenomena ini juga sudah disebutkan dalam QS. al-Furqan [25]: 53.

Dan Dialah (Allah) yang membiarkan dua laut mengalir (berdampingan), yang satu tawar dan segar dan yang lainnya asin. Dia jadikan antara keduanya dinding dan batas yang tidak tembus.

Dalam al-Qur'an juga disinggung tentang sidik jari. Setiap manusia memiliki ciri sidik jari yang unik dan berbeda antara satu orang dengan lainnya. Keunikan sidik jari baru ditemukan pada abad ke-19. Sebelum penemuan itu, sidik jari hanya dianggap sebagai lengkungan biasa yang tidak memiliki arti. QS. al-Qiyaamah [75]: 3-4 menjelaskan tentang kekuasaan Allah untuk menya-tukan kembali tulang belulang orang yang telah meninggal, bahkan Allah juga mampu menyusun kembali ujung-ujung jarinya dengan sempurna.

Apakah manusia mengira, bahwa Kami tidak akan mengumpulkan (kembali) tulang belulangnya? Bukan demikian, sebenarnya Kami kuasa menyusun (kembali) jarijemarinya dengan sempurna (QS. al-Qiyamah [75]: 3-4).

\section{Simpulan}

Grounded research adalah suatu metode penelitian yang mendasarkan 
diri kepada fakta dan menggunakan analisis perbandingan bertujuan untuk mengadakan generalisasi empiris, menetapkan konsep-konsep, membuktikan teori dan mengembangkan teori di mana pengumpulan data dan analisa data berjalan pada waktu yang bersamaan. Lebih lanjut, tujuan grounded research ialah untuk melakukan generalisasi empiris, menetapkan konsepkonsep, membuktikan teori dan mengembangkan teori.

Nazir $^{10}$ mengungkapkan bahwa terdapat beberapa ciri dari penelitian jenis grounded research, antara lain adalah penggunaan data sebagai sumber teori, menonjolkan peranan data dalam penelitian, pengumpulan data dan analisis dilakukan dalam waktu yang bersamaan, perumusan hipotesis berdasarkan kategori.

Pendekatan kontekstual Abdullah Saeed adalah salah satu di antara sekian pendekatan kontemporer yang berusaha menangkap makna tersembunyi dari teks al-Qur'an sebagai counter atas maraknya pendekatan legalistik-literalistik yang digunakan mayoritas umat Islam selama ini. dan ada juga pendekatan double movement yang dicetuskan oleh Fazlur Rahman, dan tentunya hal tersebut akan mengalami perkembangan sesuai dengan perkembangan zaman.

\section{Daftar Pustaka}

Baidan, Nashruddin. Konsepsi Taqwa Perspektif al-Qur'an. Yogyakarta: Pustaka Belajar, 2015.

Cresswell, J.W. Research Design, terj. Achmad. Fawaid. Yogyakarta: Pustaka Belajar, 2008.

Nazir, M. Metodologi Penelitian. Jakarta: Ghalia Indonesia, 1988.

Saeed, Abdullah. Interpreting the Qur'an toward a Contemporary Approach London \& New York: Routledge, 2006.

"Subhanallah, Inilah Mukjizat Alquran tentang Api di Dasar Lautan," Republika, 7 Maret 2012; www. republika.co.id/berita/m0i74b/ subhanallah-inilah-mukjizatalquran-tentang-api-di-dasarlautan. Diakses 2 Desember 2020. as-Suyuthi. Al-Itqan fi 'Ulum al-Qur'an. Beirut: Dar al-Fikr, 1979.

\footnotetext{
${ }^{10}$ Nazir, Metodologi Penelitian, 89-90.
} 